\section{Response of Container-grown Apple Trees to Soil Compaction}

\author{
D.C. Ferree and J.G. Streeter \\ Department of Horticulture and Crop Science, Ohio State University/OARDC, \\ Wooster, OH 44691
}

Y. Yuncong
Department of Horticulture, Beijing Agricultural College, Beijing 102206,
China

Additional index words. Malus $\times$ domestica, rootstock, carbohydrate, relative water content, photosynthesis, transpiration, bulk density

\begin{abstract}
Container-grown apple (Malus $\times$ domestica Borkh.) trees were exposed to soil compaction created by changing soil bulk density (SBD) to determine the effect of compaction levels, rootstock, and moisture stress on mineral nutrition, leaf gas exchange, and foliar carbohydrate levels. With SBD of $1.0,1.2$, and $1.4 \mathrm{~g} \cdot \mathrm{cm}^{-3}$, there was no interaction of rootstock and soil compaction for growth of 'Melrose' trees on nine rootstocks. Trees grown in a SBD of $1.2 \mathrm{~g} \cdot \mathrm{cm}^{-3}$ had a greater dry weight than trees at $1.4 \mathrm{~g} \cdot \mathrm{cm}^{-3}$ bulk density. Increasing SBD to $1.5 \mathrm{~g} \cdot \mathrm{cm}^{-3}$ reduced shoot length, total leaf area, leaf size, and dry weight of leaves, shoots, and roots. The interaction between rootstock and SBD was significant and total dry weight of 'B.9', 'G.16', 'G.30', and 'M.7 EMLA' was less influenced by 1.5 $\mathrm{g} \cdot \mathrm{cm}^{-3}$ soil than trees on 'M.26 EMLA' and 'MM.106 EMLA'. Withholding moisture for 10 days at the end of a 70 -day experiment caused $8 \%$ to $25 \%$ reduction in growth in a non-compacted $\left(1.0 \mathrm{~g} \cdot \mathrm{cm}^{-3}\right)$ soil with much less effect in a compacted soil. Prior to imposing the moisture stress by withholding water, net photosynthesis (Pn) was reduced $13 \%$ and transpiration (E) $19 \%$ by increasing bulk density to $1.5 \mathrm{~g} \cdot \mathrm{cm}^{-3}$. Following 7 days of moisture stress in non-compacted soil, $P$ n and $E$ were reduced $49 \%$ and $36 \%$, respectively, with no such reductions in the compacted soil. Increasing SBD to $1.5 \mathrm{~g} \cdot \mathrm{cm}^{-3}$ caused a decrease in the leaf concentration of quinic acid, myoinositol, and sucrose and an increase in fructose and glucose. Trees growing in $1.5 \mathrm{~g} \cdot \mathrm{cm}^{-3} \mathrm{had}$ reduced concentrations of $\mathrm{N}, \mathrm{Ca}$, $\mathrm{Mg}, \mathrm{Mn}, \mathrm{Na}$, and $\mathrm{Zn}$, and increased $\mathrm{P}, \mathrm{K}, \mathrm{B}$, and $\mathrm{Fe}$ in leaves.
\end{abstract}

The profitable life of an apple orchard can be 10 to 20 years after fruiting begins and, as orchard planting density increases, equipment traffic follows nearly the identical track with each pass. In production areas with abundant rainfall, soil compaction can occur due to multiple passes of heavy sprayers during the growing season and fruit removal equipment at harvest. Soil compaction resulting from the use of heavy equipment in the field can become a serious problem, especially in soils that are not regularly tilled (Blackwell et al., 1985; Brereton et al., 1986). Compaction increases the bulk density and the mechanical impedance of soil and reduces soil conductivity, permeability, and diffusivity to water and air (Vepraskas, 1994).

Effects of compaction on annual plants include restriction of root growth and, as a consequence, decreased shoot growth, leaf area development, dry matter production, and stomatal conductance (Gross, 1977; Gross and Russell, 1980). Soil compaction can significantly reduce yields of many agronomic species (Andrade et al., 1993; Blackwell et al., 1985; Brereton et al., 1986). Soil mechanical impedance and resistance to root penetration

Received for publication 13 Aug. 2002. Accepted for publication 26 Feb. 2003. Manuscript No. HCS 01-31. Salaries and research support provided by state and federal funds appropriated to the Ohio Agricultural Research and Development Center, The Ohio State Univ. increase as soils dry and, therefore, even in non-compacted soils the plant response to soil mechanical impedance is important during drought (Andrade et al., 1993). Passioura and Gardner (1990) found that the decline in growth of wheat seedlings occurred at a higher soil water content in compacted and dense soil than in loose soil.

Most of the work on the influence of soil compaction on perennial woody species has involved the use of conifer seedlings (Conlin and van den Driessche, 1996; Duffy and McClurkin, 1974) or container-grown ornamental plants (Maupin and Struve, 1997). One of the few studies on apple trees indicated that compaction of two soil types decreased dry matter production, with root growth being more affected than shoot growth (Slowik, 1970). Bulbotko (1973) also reported that SBD of 1.6 to $1.7 \mathrm{~g} \cdot \mathrm{cm}^{-3}$ inhibited the spread of apple root systems.

Mechanisms underlying the response of roots to compaction probably involve hormones as primary signals. Kays et al. (1974) noted that impeded barley roots generated ethylene. More detailed studies have extended this observation to maize (Sarquis et al., 1991) and tomato (Hussain et al., 1999b). Other studies implicate abscisic acid (ABA) as a signal transported from roots to shoots in response to mechanical impedance (Hussain et al., 1999a; Mulholland et al., 1996a, 1996b). In the latter study, ABA concentration in the xylem and stomatal conductance of barley plants were negatively correlated. For some crops, there appears to be genetic variation for improved root growth in compacted soils (Masle, 1992).

Drought stress can cause serious losses in yield and productivity of most crop plants, including apple in arid and sub-arid regions. The accumulation of solutes, such as polyols, sugars, proline, and glycine-betaine, is almost certainly an important component of the adaptation or osmotic adjustment of plants to water deficit (Daie, 1996). Transgenic plant studies have implicated carbohydrates as important osmolytes in plants subjected to water and salt stress - for example, increased drought resistance of sugar beet plants expressing a bacterial gene for fructan biosynthesis (Pilon-Smits et al., 1999); increased salt tolerance of tobacco plants expressing a bacterial gene for mannitol biosynthesis (Tarczynski et al., 1993); and increased tolerance to osmotic stress by yeast expressing a plant gene for sorbitol synthesis or a bacterial gene for mannitol biosynthesis (Shen et al., 1999).

There is accumulation of sorbitol in cherry and apple trees subjected to water deficit (Ranney et al., 1991; Wang and Stutte, 1992). Recently, this response has also been noted in peach (Lo Bianco et al., 2000). All of these studies indicate that sucrose plays a minor role in osmotic adjustment relative to sorbitol. The latter study also involved the analysis of enzymes of sucrose and sorbitol synthesis, and the combination of results indicates that sorbitol accumulation results primarily from a down-regulation of sorbitol use as opposed to up-regulation of sorbitol synthesis. Recently, a detailed study of the effects of drought on apple roots indicates higher respiration rates and greater carbohydrate costs in roots subjected to water deficit (Psarras and Merwin, 2000).

The effects of compaction on stomatal conductance of barley leaves have been noted (Hussain et al., 1999a). However, compaction of sunflower roots did not have a significant effect on photosynthesis of leaves (Andrade et al., 1993). Thus, the impact of compaction on carbon assimilation or solute accumulation in leaves is not known. To our knowledge, the interaction or combined effects of compaction and water deficit on apple trees have not been reported.

The objective of the present series of studies was to determine: 1 ) the level of soil bulk density that would cause a decrease in apple tree growth;2) whether some apple rootstocks enable trees to avoid the negative effects on growth caused by soil compaction; 3) if an interaction exists between soil compaction and soil moisture stress; and 4) if the reductions in growth caused by soil compaction are related to photosynthesis transpiration, mineral nutrients, or carbohydrates in apple leaves.

\section{Materials and Methods}

Rootstock levels of compaction. In 1997, 'Melrose' apple scions were grafted on the following commercially purchased apple root- 
stocks: 'M.27 EMLA', 'M.9 EMLA', 'M.26 EMLA', 'M.7 EMLA', 'MM.111 EMLA', 'MM.106 EMLA', 'G.30', and 'B.118'. After growing from April to November in 5.6-L containers in a medium of equal parts of peat, perlite, and soil (Wooster silt loam-Fine loamy mixed mesic typic Fragiudalf), the trees were moved to refrigerated storage $\left(7.0^{\circ} \mathrm{C}\right)$ until removal on 19 Mar. 1998. The medium was washed from the roots and all roots trimmed to a length of $5 \mathrm{~cm}$ from the rootstock shank. Trees were planted in 5.6-L containers in Orrville silt loam soil (20\%, sand, $62 \%$ silt, $18 \%$ clay, fine-loamy, mixed, active, non-acid, mesic Fluaquentic Endoaquepts). The same soil was used in all studies described here. The soil was placed in the pot in 2-cm layers and compressed with a mallet to establish bulk densities of 1.0 (control), 1.2, and $1.4 \mathrm{~g} \cdot \mathrm{cm}^{-3}$.

Treatments were arranged on the greenhouse bench in a randomized block design with three (levels of compaction) $\times$ nine (rootstock) factorial with six single-tree replications. Greenhouse temperatures were $21 \pm 3$ ${ }^{\circ} \mathrm{C}$ day $/ 15 \pm 3{ }^{\circ} \mathrm{C}$ night, and water was applied by weighing each pot regularly and returning the pot to its wet weight by submerging it briefly until the soil was saturated. Coarse pea gravel was applied to the pot surface to reduce water evaporation. Trees were trained to a single shoot and length measured monthly. Trees were harvested on $12 \mathrm{Aug}$. and divided into component parts of leaves, shoots, shank, and roots, which were dried in a forced draft oven at $70{ }^{\circ} \mathrm{C}$ and weighed.

Rootstock severe compaction. In Mar 1999, 'Red Gala \#42' trees were purchased from a commercial nursery on the following rootstocks: 'M.9 EMLA', 'G.16', 'M.26 EMLA', 'M.7 EMLA', 'G.30', and 'MM.106 EMLA'. Trees and soil were handled as previously described, except soil bulk densities were 1.0 (control) and $1.5 \mathrm{~g} \cdot \mathrm{cm}^{-3}$. In addition to the data recorded in the previous experiment, a soil penetrometer (Spectrum Technology, Plainfield, Ill.) was used to determine the level and consistency of soil compaction in containers $12 \mathrm{~h}$ after they were saturated with water. Treatments were arranged in a randomized block design with a two (levels of compaction) $\times$ six (rootstocks) factorial with six single-tree replications.

Compaction plus short-term moisture stress. On 1 June 2001, 'M.9 EMLA' apple rootstock liners were planted as previously described into soil bulk densities of either 1.0 (control) or $1.5 \mathrm{~g} \mathrm{~cm}^{-3}$. The trees were trained to a single shoot and grown as previously described. We chose M.9 because it is the most widely planted dwarfing rootstock worldwide and provides a simple plant system without the complications of a graft union. On 31 July 2001 , the soil in containers was saturated by submersion in water, and then no further water was provided to half of the trees. The design was a randomized complete-block design with treatments arranged as a two (bulk densities of 1.0 or $1.5 \mathrm{~g} \cdot \mathrm{cm}^{-3}$ ) $\times$ two (water control or moisture stress) factorial with 10 single-tree replications. Net photosynthesis and $\mathrm{E}$ were measured on the most recent fully expanded leaf after water was withheld for 7 and $10 \mathrm{~d}$, with a portable infrared gas analyzer equipped with a $6.25-\mathrm{cm}^{2}$ leaf chamber (Model LCA 2, Analytical Development Co., Hoddesdon, England). Air flow was regulated at $300 \mathrm{~mL} \cdot \mathrm{min}^{-1}$, with the air intake outside the greenhouse. Ambient $\mathrm{CO}_{2}$ concentration, humidity of the air entering and leaving the leaf chamber, the chamber temperature and incidence level of photosynthetically active radiation $(P A R)$ were recorded with each measurement. All measurements were taken with PAR above $800 \mu \mathrm{mol}$ to attain light saturation of photosynthesis.

Following measurement of $\mathrm{Pn}$ and E, the leaf was removed and immediately frozen at $-20{ }^{\circ} \mathrm{C}$. The tissue was freeze-dried and ground using a Wiley mill to pass through a 20 -mesh screen. Ground tissue was stored in tightly sealed vials at room temperature. Dried, ground tissue was simultaneously extracted and derivatized for analysis of carbohydrates by gas-liquid chromatography using an automated injector as described by Streeter and Strimbu (1998). Because the use of an internal standard gives high precision in these analyses, each sample was analyzed only once.

The major unknown peak in chromatograms was tentatively identified as quinic acid based on a retention time difference of $12 \mathrm{~s}$ between standard and sample (retention times using an automated injector are highly reproducible) and based on the lack of shoulders on the putative quinic acid peak when a proportional amount of standard was added to the samples.

The whole trees were harvested on 10 Aug. 2001, and separated into component parts and dried as previously described. The dried leaves were ground and passed through a 20-mesh screen and submitted to the Ohio State Univ. STAR Laboratory for nutrient analyses using an inductively coupled plasma (ICP) spectrophotometer (Watson and Isaac, 1990).

Compaction plus extended moisture stress. Rootstock liners of 'M.9EMLA' were planted 8 Mar. 2000, and handled as previously described with half in at $1.0 \mathrm{~g} \cdot \mathrm{cm}^{-3} \mathrm{SBD}$ and the other half in $1.5 \mathrm{~g} \cdot \mathrm{cm}^{-3} \mathrm{SBD}$. On $22 \mathrm{Apr}$. 2000, pots were submerged in water until the soil volume was thoroughly saturated. This was the final water given to the trees in the drought treatment. The statistical design was a randomized complete block with treatments arranged as a two (SBD at 1.0 or $1.5 \mathrm{~g} \cdot \mathrm{cm}^{-3}$ ) by two (watered-control or non-watered-stressed) factorial with 10 single-tree replications.

In addition to the measurements previously described in the short-term moisture stress study, relative water content was determined by removing a fully expanded leaf from each of the 10 replicate plants (different from the leaves for Pn or E measurements) weekly, beginning with the third lowest leaf on the stem. On subsequent sampling dates the 5th, 7th, 9th, etc., leaf was collected for relative water content (RWC) analysis so that the last leaves sampled were approximately in the center of each stem. The samples were taken beginning at 9:00 AM. Four leaf disks 0.8-cm diameter from each leaf were cut and weighed immediately in the greenhouse to the nearest $0.2 \mathrm{mg}$ and then floated on distilled water for $4 \mathrm{~h}$ in a covered petri dish at $4{ }^{\circ} \mathrm{C}$ to allow the disks to become fully turgid. The remainder of the test leaf was immediately placed in a plastic vial and frozen for later use to analyze for carbohydrates. The turgid disks were blotted dry and weighed; the disks were then dried overnight at $70{ }^{\circ} \mathrm{C}$ and weighed. RWC was calculated as:

[(fresh weight - dry weight)/(turgid weight - dry weight) $\times 100]$.

\section{Results}

Rootstocks level of compaction. Rootstocks are listed in Table 1 from smallest to largest based on their performance in long-term replicated field trials. Tree size in containers generally followed this order, except for trees on 'B.118', which were similar in size to the most dwarfing rootstock 'M.27 EMLA'. Trees on 'M.7 EMLA' were large relative to tree size in field trials and had a larger amount of small roots $(<2-\mathrm{mm}$ diameter) than all other rootstocks. Shoot length of trees grown in containers with a SBD of $1.4 \mathrm{~g} \cdot \mathrm{cm}^{-3}$ was less than shoot length of trees grown in less compacted soil. However, in other measurements of growth, trees in soil at $1.2 \mathrm{~g} \cdot \mathrm{cm}^{-3}$ were slightly larger than trees in soil with 1.0 or $1.4 \mathrm{~g} \cdot \mathrm{cm}^{-3}$. There was no interaction for any measure of growth between rootstock and the three levels of SBD.

Rootstock severe compaction. Rootstocks are again listed in order of their tree size in field trials for Table 2. Trees on 'M.7 EMLA' in this greenhouse study were small, while trees on 'G.16' large, relative to their expected trees size in the field. Trees on 'M.7 EMLA' had 17\% of their dry weight in roots, which was higher than most of the other rootstocks. Soil compaction caused a significant reduction in all growth parameters except the shank. The interaction between rootstock and SBD was significant for shoot length, shank and total dry weight (Fig. 1). Shoot length of trees on 'G.16' and 'B.9' were less affected by a bulk density of $1.5 \mathrm{~g} \cdot \mathrm{cm}^{-3}$ than shoot length of trees on other rootstocks. Shank dry weight of trees on 'M.26 EMLA' was reduced and on 'G.30' increased in trees growing in containers with $1.5 \mathrm{~g} \cdot \mathrm{cm}^{-3}$ SBD. When considering total dry weight trees on 'M.26 EMLA' and 'MM.106 EMLA' were significantly lighter than on other rootstocks on compacted $\left(1.5 \mathrm{~g} \cdot \mathrm{cm}^{-3}\right)$ soil. Total dry weight of trees on 'B.9', 'G.16', and 'M.7 EMLA' was not affected by a $1.5 \mathrm{~g} \cdot \mathrm{cm}^{-3} \mathrm{SBD}$.

Compaction plus short-term moisture stress. The interaction between SBD and moisture stress was significant for all measures of growth of 'M.9 EMLA' apple trees except rootstock shank (Table 3). Compacting soil to a bulk density of $1.5 \mathrm{~g} \cdot \mathrm{cm}^{-3}$ caused a $32 \%$ to $68 \%$ reduction in various growth parameters measured at the end of the 70-d experiment. While a short-term (10 d) moisture stress at the end of the growth period caused growth reductions of $8 \%$ to $25 \%$ in non-compacted soil $\left(1.0 \mathrm{~g} \cdot \mathrm{cm}^{-3}\right)$ and had much less effect on compacted soil $\left(1.5 \mathrm{~g} \cdot \mathrm{cm}^{-3}\right)$. Total dry weight in compacted soil was $13 \%$ higher in trees exposed to a moisture stress compared to those 
Table 1. Growth and tissue dry weight distribution of 'Melrose' apple trees on nine rootstocks grown in containers with soil at three bulk densities.

\begin{tabular}{|c|c|c|c|c|c|c|c|c|c|}
\hline \multirow[b]{3}{*}{ Rootstock } & \multirow{3}{*}{$\begin{array}{l}\text { Shoot } \\
\text { length } \\
(\mathrm{cm})\end{array}$} & \multirow{3}{*}{$\begin{array}{c}\text { Total } \\
\text { leaf area } \\
\left(\mathrm{cm}^{2}\right)\end{array}$} & \multirow{3}{*}{$\begin{array}{c}\text { Avg } \\
\text { leaf area } \\
\left(\mathrm{cm}^{2}\right)\end{array}$} & \multicolumn{6}{|c|}{ Dry wt distribution $(\mathrm{g})$} \\
\hline & & & & \multirow[b]{2}{*}{ Leaves } & \multirow[b]{2}{*}{ Shoot } & \multicolumn{2}{|c|}{ Root diam $(\mathrm{mm})$} & \multirow[b]{2}{*}{ Shank } & \multirow[b]{2}{*}{ Total } \\
\hline & & & & & & $<2$ & $>2$ & & \\
\hline M.27 EMLA & $81.8 \mathrm{~cd}^{\mathrm{z}}$ & $1671 \mathrm{~b}$ & $37.2 \mathrm{bc}$ & $15.3 \mathrm{~d}$ & $14.2 \mathrm{e}$ & $4.3 \mathrm{bc}$ & $1.3 \mathrm{de}$ & $17.5 \mathrm{e}$ & $52.8 \mathrm{~d}$ \\
\hline M.9 T337 & $84.2 \mathrm{~b}-\mathrm{d}$ & $1861 \mathrm{ab}$ & $40.1 \mathrm{ab}$ & $17.5 \mathrm{a}-\mathrm{c}$ & $15.9 \mathrm{c}-\mathrm{e}$ & $4.6 \mathrm{bc}$ & $2.6 \mathrm{bc}$ & $21.1 \mathrm{c}-\mathrm{e}$ & $61.8 \mathrm{bc}$ \\
\hline B.9 & $86.3 \mathrm{a}-\mathrm{d}$ & $1756 \mathrm{~b}$ & $38.9 \mathrm{ab}$ & $16.7 \mathrm{~b}-\mathrm{d}$ & $16.4 \mathrm{~b}-\mathrm{e}$ & $4.0 \mathrm{c}$ & $1.8 \mathrm{~cd}$ & $18.9 \mathrm{e}$ & $58.0 \mathrm{~cd}$ \\
\hline M.26 EMLA & $85.8 \mathrm{~b}-\mathrm{d}$ & $1828 \mathrm{ab}$ & $38.2 \mathrm{a}-\mathrm{c}$ & $17.4 \mathrm{a}-\mathrm{c}$ & $16.8 \mathrm{~b}-\mathrm{e}$ & $3.9 \mathrm{~cd}$ & $3.1 \mathrm{~b}$ & $25.5 \mathrm{a}-\mathrm{c}$ & $66.9 \mathrm{ab}$ \\
\hline M.7 EMLA & $93.4 \mathrm{a}$ & 1986 a & $40.3 \mathrm{ab}$ & $18.5 \mathrm{ab}$ & $17.2 \mathrm{a}-\mathrm{d}$ & $6.9 \mathrm{a}$ & $3.4 \mathrm{~b}$ & $24.0 \mathrm{~b}-\mathrm{d}$ & $70.1 \mathrm{ab}$ \\
\hline G.30 & $90.5 \mathrm{ab}$ & 1971 a & $40.7 \mathrm{a}$ & $19.2 \mathrm{a}$ & $19.0 \mathrm{ab}$ & $2.6 \mathrm{~d}$ & $5.5 \mathrm{a}$ & $22.0 \mathrm{c}-\mathrm{e}$ & $60.5 \mathrm{ab}$ \\
\hline MM.106 EMLA & $89.9 \mathrm{ab}$ & 2029 a & $40.3 \mathrm{ab}$ & $18.5 \mathrm{ab}$ & $19.6 \mathrm{a}$ & $5.6 \mathrm{~b}$ & $1.2 \mathrm{de}$ & $29.6 \mathrm{a}$ & $74.6 \mathrm{a}$ \\
\hline MM.111 EMLA & $88.9 \mathrm{a}-\mathrm{c}$ & $1840 \mathrm{ab}$ & $38.6 \mathrm{a}-\mathrm{c}$ & $16.2 \mathrm{~cd}$ & $18.9 \mathrm{a}-\mathrm{c}$ & $4.2 \mathrm{bc}$ & $0.5 \mathrm{e}$ & $27.1 \mathrm{ab}$ & $66.6 \mathrm{ab}$ \\
\hline B. 118 & $80.1 \mathrm{~d}$ & $1710 \mathrm{~b}$ & $35.6 \mathrm{c}$ & $15.0 \mathrm{~d}$ & $15.5 \mathrm{de}$ & $3.6 \mathrm{~cd}$ & $1.0 \mathrm{de}$ & $20.4 \mathrm{de}$ & $55.7 \mathrm{~cd}$ \\
\hline \multicolumn{10}{|c|}{ Soil bulk density $\left(\mathrm{g} \cdot \mathrm{cm}^{-3}\right)$} \\
\hline 1.0 & $87.3 \mathrm{a}$ & $1828 \mathrm{~b}$ & $39.2 \mathrm{ab}$ & $16.8 \mathrm{~b}$ & $16.7 \mathrm{~b}$ & 4.6 & 2.1 & 23.6 & $64.0 \mathrm{ab}$ \\
\hline 1.2 & $90.0 \mathrm{a}$ & 1933 a & $39.7 \mathrm{a}$ & $18.6 \mathrm{a}$ & $18.5 \mathrm{a}$ & 4.6 & 2.4 & 23.4 & $67.7 \mathrm{a}$ \\
\hline 1.4 & $83.0 \mathrm{~b}$ & $1783 \mathrm{~b}$ & $37.9 \mathrm{~b}$ & $15.9 \mathrm{~b}$ & $15.6 \mathrm{~b}$ & 4.1 & 2.3 & 21.9 & $59.9 \mathrm{~b}$ \\
\hline \multicolumn{10}{|l|}{ F Significance } \\
\hline Rootstock (RS) & ** & ** & * & ** & ** & $* *$ & ** & $* *$ & ** \\
\hline Bulk density (BD) & ** & $*$ & NS & ** & ** & NS & NS & NS & $* *$ \\
\hline $\mathrm{RS} \times \mathrm{BD}$ & NS & NS & NS & NS & NS & NS & NS & NS & NS \\
\hline
\end{tabular}

${ }^{2}$ Mean separation for main effects of rootstock and bulk density by Duncan's multiple range, $P<0.05$.

ss, ${ }^{*}, *$ Nonsignificant or significant at $P<0.05$ or 0.01 , respectively.

Table 2. Growth and dry weight distribution of 'Red Gala 42' apple trees on six rootstocks grown in containers with soil at two bulk densities.

\begin{tabular}{|c|c|c|c|c|c|c|c|c|}
\hline \multirow[b]{2}{*}{ Rootstock } & \multirow{2}{*}{$\begin{array}{l}\text { Shoot } \\
\text { length } \\
(\mathrm{cm})\end{array}$} & \multirow{2}{*}{$\begin{array}{c}\text { Total } \\
\text { leaf area } \\
\left(\mathrm{cm}^{2}\right)\end{array}$} & \multirow{2}{*}{$\begin{array}{c}\text { Avg } \\
\text { leaf area } \\
\left(\mathrm{cm}^{2}\right)\end{array}$} & \multicolumn{5}{|c|}{ Dry wt distribution $(\mathrm{g})$} \\
\hline & & & & Leaves & Shoot & Roots & Shank & Total \\
\hline$\overline{B .9}$ & 93.9 & $2363 a b^{2}$ & $47.2 \mathrm{a}$ & $20.8 \mathrm{a}$ & $23.3 \mathrm{ab}$ & $16.0 \mathrm{bc}$ & $92.2 \mathrm{~b}$ & $152.5 \mathrm{c}$ \\
\hline G.16 & 95.9 & $2177 \mathrm{a}-\mathrm{c}$ & $41.3 \mathrm{a}-\mathrm{c}$ & $18.2 \mathrm{ab}$ & $25.8 \mathrm{a}$ & $19.4 \mathrm{ab}$ & $123.2 \mathrm{a}$ & $186.7 \mathrm{a}$ \\
\hline M.26 EMLA & 93.0 & $2169 a-c$ & $43.4 \mathrm{ab}$ & $17.8 \mathrm{ab}$ & $20.5 \mathrm{~b}$ & $13.0 \mathrm{c}$ & $115.9 \mathrm{a}$ & $197.3 \mathrm{bc}$ \\
\hline M.7 EMLA & 93.1 & $1804 \mathrm{c}$ & $36.4 \mathrm{c}$ & $14.4 \mathrm{~b}$ & $18.2 \mathrm{~b}$ & $22.2 \mathrm{a}$ & $74.3 \mathrm{c}$ & $129.2 \mathrm{~d}$ \\
\hline G.30 & 84.2 & $2516 \mathrm{a}$ & $47.4 \mathrm{a}$ & $20.6 \mathrm{a}$ & $26.1 \mathrm{a}$ & $19.0 \mathrm{ab}$ & $109.1 \mathrm{a}$ & $174.9 \mathrm{ab}$ \\
\hline MM.106 & 100.0 & $2005 \mathrm{bc}$ & $39.1 \mathrm{bc}$ & $17.4 \mathrm{ab}$ & $23.1 \mathrm{ab}$ & $12.1 \mathrm{c}$ & $54.1 \mathrm{~d}$ & $106.9 \mathrm{e}$ \\
\hline \multicolumn{9}{|c|}{ Soil bulk density $\left(\mathrm{g} \cdot \mathrm{cm}^{-3}\right)$} \\
\hline 1.0 & 111.9 & 2738 & 50.4 & 22.5 & 27.3 & 18.4 & 93.8 & 162.2 \\
\hline 1.5 & 73.6 & 1584 & 34.4 & 13.7 & 18.2 & 15.1 & 95.7 & 142.8 \\
\hline \multicolumn{9}{|l|}{ F Significance } \\
\hline Rootstock (RS) & $*$ & * & $* *$ & ** & ** & $* *$ & $* *$ & $* *$ \\
\hline Bulk density (BD) & $* *$ & $* *$ & $* *$ & $* *$ & ** & * & NS & ** \\
\hline $\mathrm{RS} \times \mathrm{BD}$ & * & NS & NS & NS & NS & NS & ** & $* *$ \\
\hline
\end{tabular}

${ }^{ }$Mean separation for main effects of rootstock and bulk density by Duncan's multiple range test, $P<0.05$

Ns, ,*** Nonsignificant or significant at $P<0.05$ or 0.01 , respectively.

with no moisture stress.

Trees grown for $60 \mathrm{~d}$ in compacted soil had a $13 \%$ reduction in $\mathrm{Pn}$ and a $19 \%$ reduction in $\mathrm{E}$ prior to imposing a moisture stress (Table 4). In the compacted soil, moisture stress had no significant influence on Pn or E. After $10 \mathrm{~d}$ of withholding water, Pn and E were significantly reduced in both compacted and non-compacted soil, but the reduction was greatest in the latter. After $7 \mathrm{~d}$ of withholding water, Pn of trees in the non-compacted soil was reduced $49 \%$ and $\mathrm{E} 36 \%$.

Increasing SBD to $1.5 \mathrm{~g} \cdot \mathrm{cm}^{-3}$ caused a decrease in leaf quinic acid, myo-inositol and sucrose, and an increase in fructose and glucose (Table 5). The response was similar after 7 or $10 \mathrm{~d}$ of water stress, except sucrose concentration was not different after $10 \mathrm{~d}$. After $7 \mathrm{~d}$ of moisture stress, leaf concentrations of quinic acid and sorbitol were reduced, while after $10 \mathrm{~d}$ of moisture stress all carbohydrate fractions, except quinic acid, were reduced. The significant interaction with sorbitol after $7 \mathrm{~d}$ of moisture stress was due to stable concentrations at $1.5 \mathrm{~g} \cdot \mathrm{cm}^{-3}$, but a $17 \%$ increase associated with water stress in leaves from trees on noncompacted $\left(1.0 \mathrm{~g} \cdot \mathrm{cm}^{-3}\right)$ soil.
Increasing SBD to $1.5 \mathrm{~g} \cdot \mathrm{cm}^{-3}$ resulted in a significant decrease in leaf concentrations of $\mathrm{N}, \mathrm{Ca}, \mathrm{Mg}, \mathrm{Mn}, \mathrm{Na}$, and $\mathrm{Zn}$ and significant increases in $\mathrm{P}, \mathrm{K}, \mathrm{B}$, and $\mathrm{Fe}$ (Table 6). The $10 \mathrm{~d}$ of moisture stress caused an increase in iron. The only other leaf nutrient affected by the moisture stress was B, which was not affected in non-compacted soil $\left(1.0 \mathrm{~g} \cdot \mathrm{cm}^{-3}\right)$, but decreased $10 \%$ in trees grown in compacted $\left(1.5 \mathrm{~g} \cdot \mathrm{cm}^{-3}\right)$ soil.

Compaction plus extended moisture stress. Soil compaction $\left(1.5 \mathrm{~g} \cdot \mathrm{cm}^{-3}\right)$ on well-watered plants reduced height by $43 \%$, stem diameter by $15 \%$, number of leaves $32 \%$, and leaf area $34 \%$ to $49 \%$ compared to controls depending on what portion of the tree was sampled (Table 7). Stressing the trees by withholding moisture for $32 \mathrm{~d}$ caused the following reductions in growth: height $31 \%$, stem diam $7 \%$, number of leaves $23 \%$, and leaf area $15 \%$ to $68 \%$ with the greatest effect on upper leaves. A significant interaction occurred between compaction and moisture stress, as moisture stress had less effect on growth in the compacted soil. Measuring the rate of water loss from the pots by weighing showed that loss from the compacted pots was half that of the non-compacted during the first week of withholding water. This trend continued until 17 May when rate of water loss in the stressed treatments was near zero for trees in both compacted and non-compacted soils. Plants on all treatments had similar RWC 1 week after the initiation of moisture treatments (Fig. 2). However, 2 weeks later, the trend toward lower RWC in stressed plants was apparent. By 22 May, RWC in moisture-stressed trees was much lower than the controls. Analysis of variance (ANOVA) for 1 and 15 May indicated highly significant effects of both stress and compaction. The most striking difference was between moisture-stressed trees growing in compacted and non-compacted soil. That is, because of a substantially greater rate of water loss from trees growing in non-compacted soil, leaves on these trees had very low RWC. In the week following re-watering (24 May), RWC in all leaves was similar.

Photosynthesis and transpiration were lower in moisture-stressed plants for essentially all of the sampling dates and this was true regardless of compaction (Fig. 3). Thus, moisture stress and non-compaction of soil had the most significant impact on these parameters. 
ANOVAindicated a statistically significant effect of compaction on transpiration only for the 3 and 10 May sampling dates. There was a tendency for trees growing in compacted soil to have slightly higher rates of photosynthesis and transpiration on 17 May and 1 June, and this trend was much clearer for the well-watered plants. The photosynthetic activity of moisture-stressed trees did not fully recover following rewatering. A positive correlation $\left(\mathrm{r}=0.76^{* *}\right)$ was noted between Pn and RWC for the moisture-stressed/non-compacted treatment, but the coefficient for moisture-stressed plants in compacted soil was nonsignificant. Correlations between transpiration and RWC were significant for moisture-stressed trees in both compacted $\left(\mathrm{r}=0.58^{*}\right)$ and non-compacted $\left(\mathrm{r}=0.69^{* *}\right)$ treatments.

Results for the carbohydrate composition in trees with the moisture-stressed non-compacted treatment on 22 May were erratic and may not be valid. Trees were severely stressed on this date, having an extremely low RWC of $38 \%$ (Fig. 2), and photosynthetic and transpiration rates of near zero (Fig. 3). That plants in this treatment were more severely stressed than plants in the moisture-stressed one, and compacted treatment is probably due to more rapid withdrawal of water from the root volume of non-compacted plants.

For the sample on 6 May, collection of leaf samples had to be delayed until 1:00 PM. RWC values were unusually low, and data for carbohydrates that are relatively rapidly metabolized (e.g., glucose and fructose) were also low in well-watered plants. Rather than select certain data to report for this sampling, all of the data were considered atypical and are not presented. The major difference in results caused by a 4-h delay in sampling emphasizes the importance of consistency in the time of day when samples are obtained, especially for RWC.

For well-watered treess in compacted soil, leaf sucrose concentrations were very high relative to non-compacted plants (Fig. 4A). Also, whereas sucrose concentration in the well-watered $1.5 \mathrm{~g} \cdot \mathrm{cm}^{-3}$ treatment increased slightly and then declined sharply, sucrose in the well-watered $1.0 \mathrm{~g} \cdot \mathrm{cm}^{-3}$ treatment was flat over time. For trees subjected to soil compaction, sucrose concentration tended to be higher in leaves of moisture-stressed trees, but there was an anomalous switch in this relationship for the leaves sampled on 22 May, probably due to the severe stress level in the moisture-stressed non-compacted trees, as noted above. Results of ANOVA for the 1 and 15 May dates indicated significant effects for both the moisture stress and compaction treatments.

Glucose concentration in leaves of trees not moisture stressed showed random variations over time, but no clear trends (Fig. 4B). In contrast, glucose in leaves of moisture-stressed plants showed a weak trend toward increasing concentrations over time. For neither group of trees did there appear to be an effect of compaction. Similar trends were seen for fructose concentration (Fig. 4D), although the concentration of fructose in leaves was much less than the concentration of either sucrose or glucose.
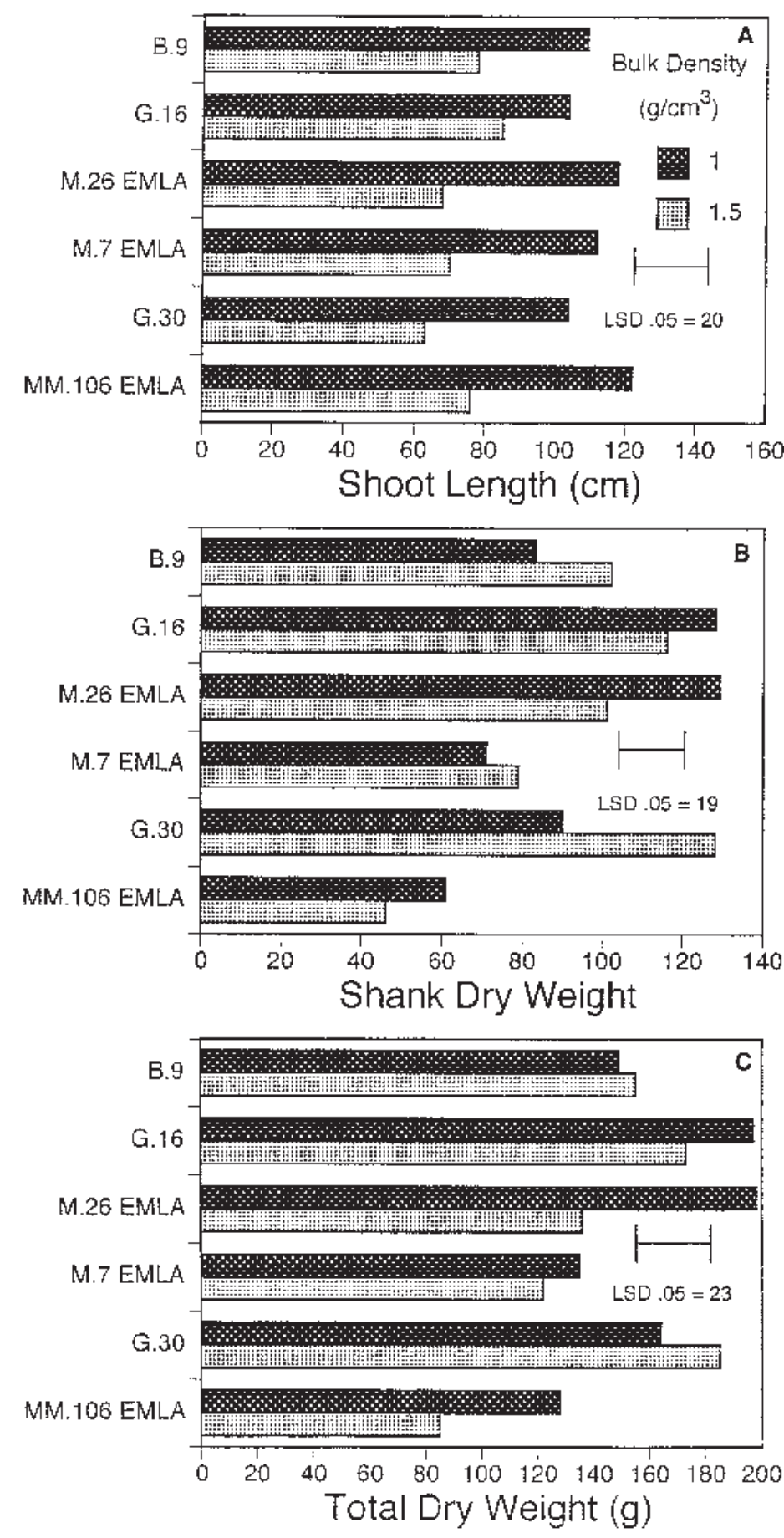

Fig. 1. Interaction of 'Gala' on six apple rootstocks and container SBD on (A) shoot length, (B) shank dry weight, and (C) total dry weight.

Table 3. Growth and tissue dry weight distribution of 'M.9 EMLA' trees grown in containers in soil at two bulk densities with and without a moisture stress.

\begin{tabular}{|c|c|c|c|c|c|c|c|}
\hline \multirow[b]{2}{*}{ Soil bulk density $\left(\mathrm{g} \cdot \mathrm{m}^{-3}\right)$} & \multirow{2}{*}{$\begin{array}{l}\text { Shoot } \\
\text { length } \\
(\mathrm{cm})\end{array}$} & \multirow{2}{*}{$\begin{array}{c}\text { Leaf } \\
\text { area } \\
\left(\mathrm{cm}^{2}\right)\end{array}$} & \multicolumn{5}{|c|}{ Dry wt distribution (g) } \\
\hline & & & Leaves & Shoot & Shank & Root & Total \\
\hline 1.0 Control & 61.8 & 1512 & 10.65 & 8.45 & 29.1 & 13.44 & 61.69 \\
\hline Moisture stress & 56.7 & 1210 & 9.00 & 6.73 & 31.2 & 10.07 & 57.00 \\
\hline 1.5 Control & 33.4 & 483 & 3.50 & 2.27 & 27.7 & 8.46 & 41.99 \\
\hline Moisture stress & 34.9 & 534 & 3.72 & 2.46 & 30.9 & 11.15 & 48.30 \\
\hline $\mathrm{LSD}_{0.05}$ & 4.2 & 123 & 0.36 & 0.71 & NS & 2.72 & 5.42 \\
\hline F Significance & & & & & & & \\
\hline Bulk density (BD) & $* *$ & $* *$ & $* *$ & $* *$ & NS & * & $* *$ \\
\hline Moisture stress (MS) & NS & $* *$ & * & $* *$ & NS & NS & NS \\
\hline $\mathrm{BD} \times \mathrm{MS}$ & $*$ & $*$ & $* *$ & $* *$ & NS & $* *$ & $* *$ \\
\hline
\end{tabular}

Ns, ${ }^{*, * *}$ Nonsignificant or significant at $P<0.05$ or 0.01 , respectively. 


\section{Crop Production}

Table 4. Net photosynthesis (Pn) and transpiration (E) of leaves of 'M.9 EMLA' apple trees grown in containers in soil at two bulk densities with and without a moisture stress.

\begin{tabular}{|c|c|c|c|c|c|c|}
\hline \multirow[b]{3}{*}{ Soil bulk densities $\left(\mathrm{g} \cdot \mathrm{cm}^{-3}\right)$} & \multicolumn{6}{|c|}{$\operatorname{Pn}\left(\mu \mathrm{mol} \cdot \mathrm{CO}_{2} \cdot \mathrm{m}^{-1} \cdot \mathrm{s}^{-1}\right.$ and $\mathrm{E}\left(\mu \mathrm{g} \cdot \mathrm{H}_{2} \mathrm{Os}^{-1}\right)$} \\
\hline & \multicolumn{2}{|c|}{31 July } & \multicolumn{2}{|c|}{7 Aug. } & \multicolumn{2}{|c|}{10 Aug. } \\
\hline & $\mathrm{Pn}$ & $\mathrm{E}$ & $\mathrm{Pn}$ & $\mathrm{E}$ & $\mathrm{Pn}$ & E \\
\hline $1.0 \mathrm{~W}^{2}$ & 19.5 & 15.5 & 18.6 & 13.2 & 14.6 & 10.8 \\
\hline $\mathrm{S}$ & 19.7 & 15.6 & 9.6 & 8.5 & 3.4 & 3.1 \\
\hline $1.5 \mathrm{~W}$ & 16.9 & 12.6 & 15.4 & 9.4 & 12.2 & 9.0 \\
\hline $\mathrm{S}$ & 18.0 & 13.4 & 13.4 & 8.8 & 6.7 & 5.0 \\
\hline $\mathrm{LSD}_{0.05}$ & NS & NS & 2.6 & 1.2 & 2.4 & 1.6 \\
\hline \multicolumn{7}{|l|}{ F Significance } \\
\hline Bulk density (BD) & ** & ** & NS & ** & NS & NS \\
\hline Moisture stress (MS) & NS & NS & $* *$ & ** & ** & ** \\
\hline $\mathrm{BD} \times \mathrm{MS}$ & NS & NS & $* *$ & ** & ** & ** \\
\hline
\end{tabular}

${ }^{2}$ Moisture withheld after the measurements on 31 July (S) and compared to well-watered trees (W) with 7 and 10 Aug. measurements after 7 and $10 \mathrm{~d}$ of withholding moisture.

Ns, ${ }^{*}, *$ Nonsignificant or significant at $P<0.05$ or 0.01 , respectively.

Table 5. Leaf carbohydrate concentration (mg.g ${ }^{-1}$ dry wt.) of 'M.9 EMLA' apple trees grown in soil at two bulk densities with and without a moisture stress.

\begin{tabular}{|c|c|c|c|c|c|c|c|c|c|c|c|c|}
\hline \multirow{2}{*}{$\begin{array}{l}\text { Soil bulk density } \\
\left(\mathrm{g} \cdot \mathrm{cm}^{-3}\right)\end{array}$} & \multicolumn{6}{|c|}{ After $7 \mathrm{~d}$ of moisture stress } & \multicolumn{6}{|c|}{ After $10 \mathrm{~d}$ of moisture stress } \\
\hline & Quinic acid & Sorbitol & Fructose & Glucose & Myoinositol & Sucrose & Quinic acid & Sorbitol & Fructose & Glucose & Myoinositol & Sucrose \\
\hline 1.0 & 129 & 379 & 9.1 & 68 & 6.3 & 114 & 153 & 470 & 10.3 & 69 & 6.8 & 88 \\
\hline 1.5 & 110 & 256 & 13.7 & 94 & 5.6 & 79 & 128 & 475 & 14.1 & 97 & 6.0 & 77 \\
\hline \multicolumn{13}{|l|}{ Moisture stress } \\
\hline Control & 126 & 349 & 11.6 & 77 & 6.1 & 100 & 144 & 433 & 8.7 & 56 & 6.8 & 107 \\
\hline Stress & 113 & 386 & 11.2 & 85 & 5.8 & 93 & 136 & 512 & 15.7 & 110 & 6.0 & 58 \\
\hline \multicolumn{13}{|l|}{ F Significance } \\
\hline Bulk density (BD) & ** & NS & * & * & ** & ** & ** & NS & * & ** & ** & NS \\
\hline Stress (S) & $*$ & $* *$ & NS & NS & NS & NS & NS & $* *$ & $* *$ & $* *$ & $* *$ & $* *$ \\
\hline $\mathrm{BD} \times \mathrm{S}$ & NS & $* *$ & NS & NS & NS & NS & NS & NS & NS & NS & NS & NS \\
\hline
\end{tabular}

ws, *,**Nonsignificant or significant at $P<0.05$ or 0.01 , respectively.

Table 6. Minimal nutrient concentrations in leaves of 'M.9 EMLA' apple trees grown in containers in soil at two bulk densities with and without a moisture stress of $10 \mathrm{~d}$.

\begin{tabular}{|c|c|c|c|c|c|c|c|c|c|c|}
\hline \multirow{2}{*}{$\begin{array}{l}\text { Soil bulk density } \\
\left(\mathrm{g} \cdot \mathrm{cm}^{-3}\right)\end{array}$} & \multicolumn{5}{|c|}{$\%$ Dry wt } & \multicolumn{5}{|c|}{$\mu \mathrm{g} \cdot \mathrm{g}^{-1}$ Dry wt } \\
\hline & $\mathrm{N}$ & $\mathrm{P}$ & $\mathrm{K}$ & $\mathrm{Ca}$ & $\mathrm{Mg}$ & B & $\mathrm{Fe}$ & $\mathrm{Mn}$ & $\mathrm{Na}$ & $\mathrm{Zn}$ \\
\hline 1.0 & 2.62 & 0.16 & 1.48 & 1.63 & 0.43 & 19.9 & 56.6 & 79.4 & 639 & 29.5 \\
\hline 1.5 & 2.52 & 0.18 & 1.66 & 1.16 & 0.30 & 26.7 & 62.1 & 40.2 & 114 & 23.1 \\
\hline \multicolumn{11}{|l|}{ Water stress } \\
\hline Control & 2.58 & 0.17 & 1.59 & 1.40 & 0.37 & 23.9 & 55.6 & 59.0 & 12 & 427.7 \\
\hline Stress & 2.58 & 0.17 & 1.55 & 1.39 & 0.37 & 22.7 & 63.1 & 60.7 & 125 & 24.9 \\
\hline \multicolumn{11}{|l|}{ F Significance } \\
\hline Bulk density (BD) & * & $* *$ & ** & ** & ** & ** & ** & ** & ** & * \\
\hline Stress (S) & NS & NS & NS & NS & NS & * & $* *$ & NS & NS & NS \\
\hline $\mathrm{BD} \times \mathrm{S}$ & NS & NS & NS & NS & NS & *** & NS & NS & NS & NS \\
\hline
\end{tabular}

Ns, **** Nonsignificant or significant at $P<0.05$ or 0.01 , respectively.

Table 7. Effect of container soil bulk density and moisture stress on growth of 'M.9 EMLA' apple trees over 77 d.

\begin{tabular}{|c|c|c|c|c|c|c|c|c|c|}
\hline \multirow{3}{*}{$\begin{array}{l}\text { Soil bulk density } \\
\left(\mathrm{g} \cdot \mathrm{cm}^{-3}\right)\end{array}$} & \multirow{3}{*}{$\begin{array}{c}\text { Moisture }^{2} \\
\text { stress }\end{array}$} & \multicolumn{2}{|c|}{ Plant ht (m) } & \multirow{3}{*}{$\begin{array}{l}\text { Stem } \\
\text { diam } \\
(\mathrm{mm})\end{array}$} & \multicolumn{2}{|c|}{ No. of leaves } & \multirow{2}{*}{\multicolumn{3}{|c|}{ Avg. leaf area $\left(\mathrm{cm}^{2}\right)$}} \\
\hline & & & Change & & & Change & & & \\
\hline & & 24 May & $\overline{22 \text { Apr.-24 May }}$ & & 24 May & $\overline{22 \text { Apr.-24 May }}$ & Lower & Middle & $\overline{\text { Upper }}$ \\
\hline 1.0 & $\mathrm{~W}$ & 94.5 & 23.9 & 8.8 & 42.1 & 13.8 & 34.2 & 33.2 & 69.9 \\
\hline 1.5 & $\mathrm{~W}$ & 53.7 & 15.7 & 7.5 & 28.6 & 9.3 & 19.2 & 22.1 & 36.2 \\
\hline 1.0 & $\mathrm{~S}$ & 65.4 & 5.6 & 8.2 & 32.6 & 5.7 & 28.9 & 28.3 & 22.2 \\
\hline 1.5 & $\mathrm{~S}$ & 50.2 & 6.2 & 7.4 & 24.7 & 4.5 & 20.9 & 21.2 & 19.9 \\
\hline $\mathrm{LSD}_{0.05}$ & & 6.3 & 3.9 & 0.4 & 3.1 & 2.2 & 1.1 & 1.0 & 2.5 \\
\hline \multicolumn{10}{|l|}{ F Significance } \\
\hline Bulk density (BD) & & $* *$ & ** & $* *$ & ** & ** & ** & ** & ** \\
\hline Stress (S) & & ** & ** & ** & ** & ** & ** & ** & $* *$ \\
\hline $\mathrm{BD} \times \mathrm{S}$ & & ** & ** & NS & ** & ** & NS & NS & NS \\
\hline
\end{tabular}

${ }^{2}$ Trees planted 8 Mar. and watered as needed until the soil was saturated on 22 Apr. and following that date, half were watered as needed (W), and half were not watered (S) until soil in all pots was saturated 24 May.

Ns,, , ** Nonsignificant or significant at $P<0.05$ or 0.01 , respectively. 


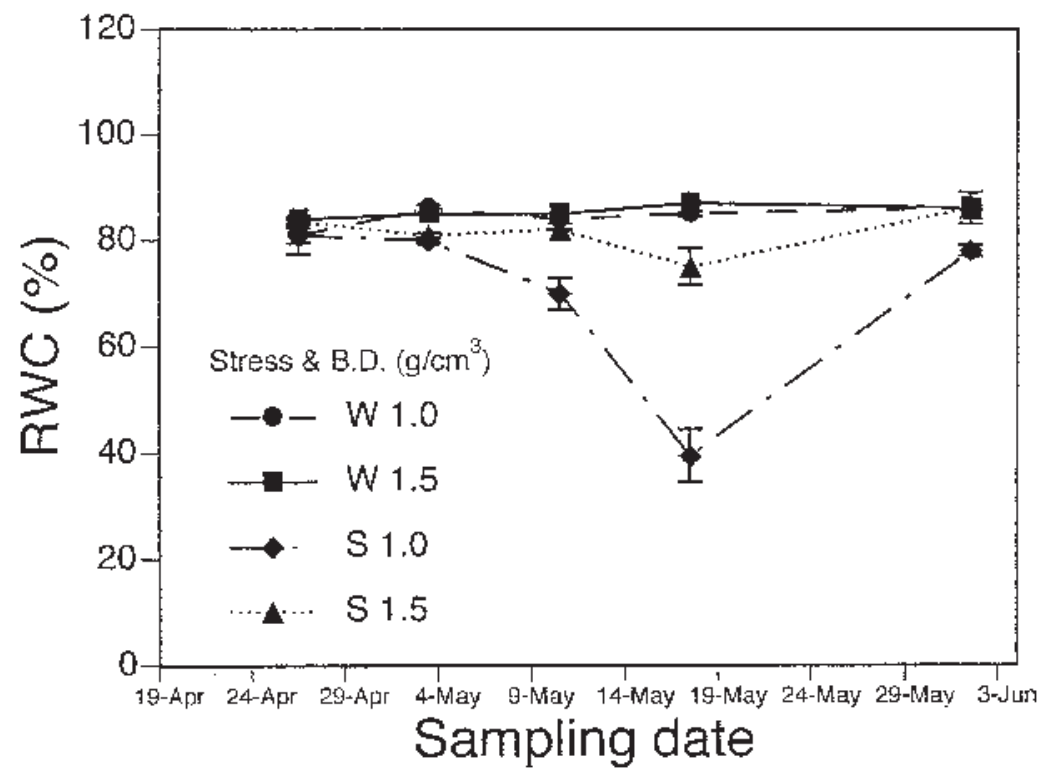

Fig. 2. Effect of container SBD and water stress (W = watered; $S=$ not watered) on relative water content of 'M.9 EMLA' apple leaves. Soil was saturated with water just prior to 19 Apr. and just after 23 May.

As expected, the major carbohydrate in leaves was sorbitol. Effects of treatments on sorbitol concentration were complex, but in general, trees in non-compacted soil had higher sorbitol concentrations (Fig. 4C). ANOVA confirmed the highly significant effect of compaction on sorbitol concentration on 1 and 15 May. Note that, for the period from 15 to 29 May, the sucrose and sorbitol concentrations in the moisture-stressed noncompacted treatment were mirror images in terms of concentration changes. Except for the well-watered non-compacted controls, the general trend in leaf sorbitol concentration during the period of moisture stress was an increase, the increase being particularly large in the compacted + moisture-stressed plants. Sorbitol concentration in leaves was significantly correlated with photosynthetic activity for the well-watered non-compacted treatment $\left(\mathrm{r}=0.50^{*}\right)$ and the moisture-stressed compacted treatment $\left(\mathrm{r}=0.90^{* *}\right)$, but not for the other two treatments.

The concentration of myoinositol in apple leaves was low (1-6 $\mathrm{mg} \cdot \mathrm{g}^{-1}$ dry weight) relative to other compounds at all sampling times. Quinic acid ranged from $60-95 \mathrm{mg} \cdot \mathrm{g}^{-1}$ dry weight. Although ANOVA indicated some significant treatment effects at a few dates for these compounds, the plotted data revealed no meaningful trends across time (data not shown).

In view of the lack of significant effect of compaction on photosynthesis (Fig. 3 and ANOVA results), it is curious that there were large and statistically significant effects of compaction on sorbitol (Fig. 4C and ANOVA results). In the leaves of well-watered and moisture-stressed trees, the average decrease in sorbitol concentration for the samples taken during the onset of moisture stress was 151 and 116 $\mathrm{mg} \cdot \mathrm{g}^{-1}$ dry weight, respectively. These amounts represent $33 \%$ of the sorbitol concentration found in leaves on non-compacted plants, so the effect of compaction was substantial. The decline in sorbitol was accompanied by an increase in sucrose concentration in leaves, although the quantitative increase in sucrose cannot account for the decline in sorbitol. Also, the increase in sucrose in moisture-stressed plants in response to compaction was only about half that in the well-watered controls. Effects of compaction on the concentration of glucose and other carbohydrates were either small or inconsistent. In contrast, the reciprocal effects of compaction on sucrose and sorbitol were very consistent across time. This suggests that hexose was diverted from sorbitol synthesis to sucrose synthesis, but how this might be caused by soil compaction is difficult to explain.

\section{Discussion}

Although it is not possible to extrapolate to field conditions from these greenhouse studies, this work indicates that a wide range of apple rootstocks are tolerant of SBD to $1.4 \mathrm{~g} \cdot \mathrm{cm}^{-3}$ in silt loam soils (Table 1). Increasing bulk density to $1.5 \mathrm{~g} \cdot \mathrm{cm}^{-3}$ (Table 2) caused $80 \%$ (771 vs. $3720 \mathrm{kPa}$ for $1.5 \mathrm{~g} \cdot \mathrm{cm}^{-3}$ ) greater resistance measured by a penetrometer compared to $1.0 \mathrm{~g} \cdot \mathrm{cm}^{-3}$ soil, and this caused significant reductions in shoot growth, with greater effects on some rootstocks than others. Work of Slowik (1970) with apple also reported no compaction effect below $1.4 \mathrm{~g} \cdot \mathrm{cm}^{-3}$. Work with red oak (Quercus rubra L.) in Wooster silt loam soil (25\% sand, $60 \%$ silt, $15 \%$ clay) indicated growth was not influenced by 1.5 , but was reduced at $1.75 \mathrm{~g} \cdot \mathrm{cm}^{-3}$ bulk density (Maupin and Struve, 1997). With pine seedlings, the tallest seedlings occurred at the highest compaction levels in a loam soil (46\% sand, $47 \%$ silt, $7 \%$ clay), but compaction above $1.7 \mathrm{~g} \cdot \mathrm{cm}^{-3}$ caused decreased needle length and root dry weight (Conlin and van den Driessche, 1996). Although it is not possible to make direct comparisons among these studies because bulk density depends on soil types, apple trees appear similar or slightly more sensitive to soil compaction than these other tree species.

The greater sensitivity of some rootstocks to soil compaction of $1.5 \mathrm{~g} \cdot \mathrm{cm}^{-3}$ confirms work of Slowik (1970), who studied a more limited range of rootstocks. He found 'M.26' and 'M.4' more sensitive than 'Antonovka' seedlings, and 'M.26' was also sensitive in our study (Table 2 ). Tree size in the field does not seem like the determining factor in sensitivity, as both 'M.26' (dwarfing) and 'MM.106' (semi-standard) were sensitive. 'B.9' (dwarfing), 'M.7 EMLA', and 'G.30' (semi-standard) were tolerant based on total dry weight, and the new 'G.16', which is similar to 'M.9' in tree size, was also reasonably tolerant (Fig. 1). Masle (1992) has suggested that growth responses to soil compaction vary considerably between plant species and also between genotypes within species. Genotypes with lower growth rates in non-compacted soils will respond less to soil compaction than genotypes with high growth rates. The relative growth rates of root systems of apple rootstocks is not known, but may be linked with the difference in response. A field comparison will be required to confirm that these dwarfing rootstocks, which are promising for modern intensive orchards, have some tolerance to soil compaction. However, soil compaction should be avoided if possible because shoot length of trees on all rootstocks was reduced by a SBD of $1.5 \mathrm{~g} \cdot \mathrm{cm}^{-3}$.

One of the most interesting and surprising results is that, although compaction had major effects on plant growth (Tables 2 and 3; Fig. 1), there was relatively little effect of compaction on photosynthesis (Table 4;Fig. 3), suggesting that carbon supply was not the major factor limiting growth under compacted soil conditions. Similar effects of compaction on growth of barley (Hordeum wulgare L.) plants have been reported (Gross, 1977; Gross and Russell, 1980; Hussain et al., 1999a). Reports on the effect of soil compaction on wheat (Triticum aestivum L.) (Masle and Farquhar, 1988) and sunflower (Helianthus annus L.) (Andrade et al., 1993) show that the rate of photosynthesis was equal to or, in some cases, higher than in plants growing in non-compacted soil even though total photosynthetic leaf area had been reduced by soil compaction. However, photosynthesis of Pinus contorta was decreased by soil compaction (Conlin and van den Driessche, 1996).

Soil compaction had major effects on transpiration and RWC, and often the response was positive in trees growing in compacted soil. These effects of compaction were small relative to the effects of moisture stress (Table 4; Figs. 2 and 3). Increasing soil compaction had little effect on the water relations of red oak (Maupin and Struve, 1997), barley (Mulholland et al., 1996a, 1996b), sunflower (Andrade et al., 1993), and wheat (Masle and Farquhar, 1988) under conditions of adequate soil moisture. A bulk density of $1.5 \mathrm{~g} \cdot \mathrm{cm}^{-3}$ had no effect on transpiration under adequate soil moisture. However, this level of soil compaction resulted in higher transpiration rates compared to trees 

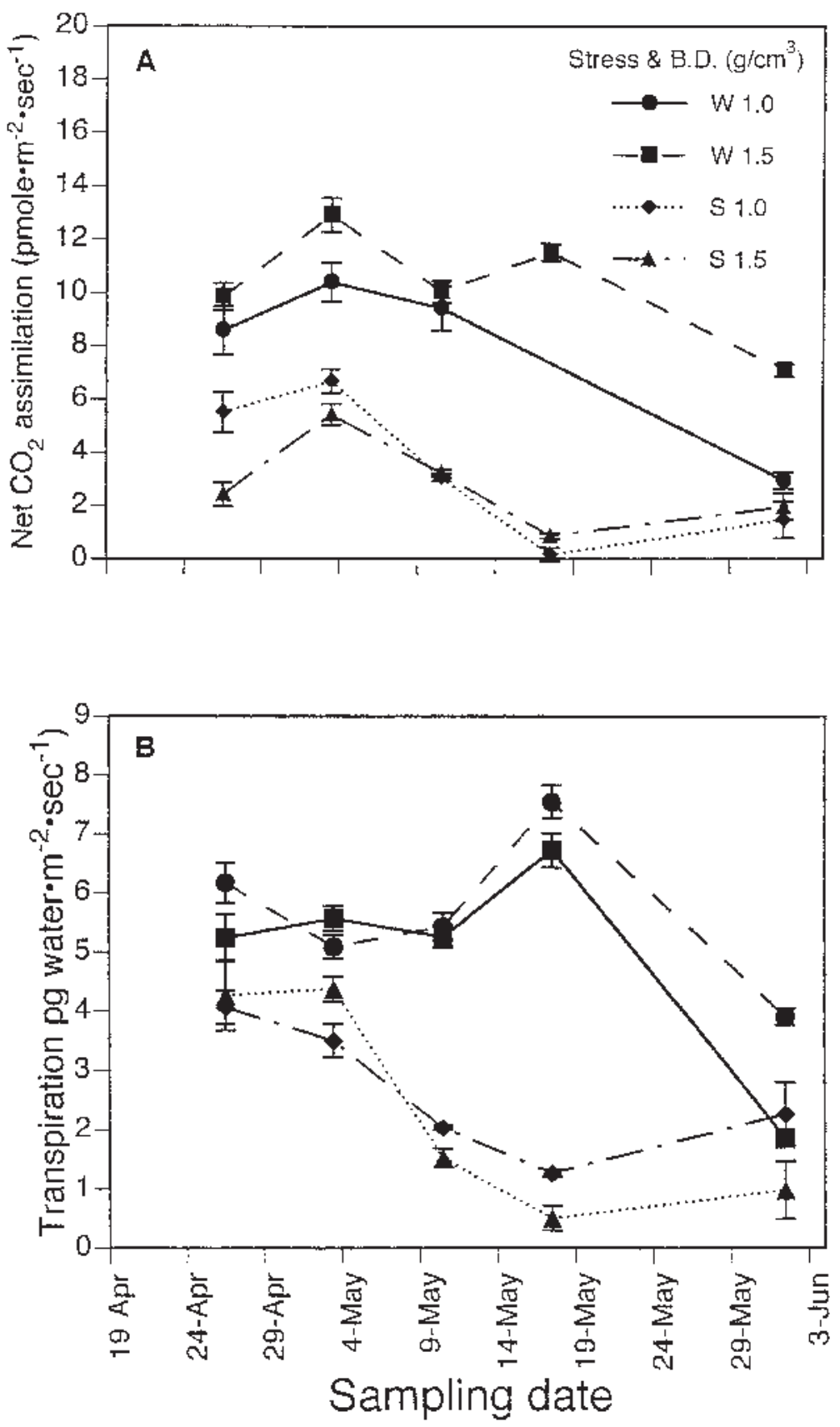

Fig. 3. Effect of container SBD and water stress (W = watered; $\mathrm{S}=$ not watered) on (A) net photosynthesis and (B) transpiration of 'M.9 EMLA' apple leaves. Soil was saturated with water just prior to 19 Apr. and just after 23 May.

growing in $1.0 \mathrm{~g} \cdot \mathrm{cm}^{-3}$ soil when water was withheld, due to more rapid loss of water from the non-compacted soil. Thus, the data suggest that if water is available, moderate compaction does not greatly affect the ability of the plant to take up water. Compaction appears to slow soil water loss as moisture stress develops, thus permitting these trees to maintain a higher level of transpiration. On fine-textured soils (as used in our studies), soybean yields were higher in dry years on compacted soils than in wet years, while the reverse was evident on coarse-textured soil (Vepraskas, 1994).

'M.9 EMLA' rootstock was selected as the plant material for these studies because it is the most widely planted dwarfing apple rootstock and was reportedly more tolerant of soil moisture deficit (Fernandez et al., 1997) and soil compaction (Ferree and Schmid, 2001) compared to other rootstocks. In a study of root distribution, 'M.9 EMLA' had a higher root density than 'Mark' at all soil depths from 59 to $132 \mathrm{~cm}$ in a soil with bulk densities of 1.5 $\mathrm{g} \cdot \mathrm{cm}^{-3}$ (Fernandez et al., 1995).

In apple, sorbitol is the major product of photosynthesis and is the major translocated form of carbon (Loescher et al., 1982). Sorbitol is also an important reserve carbohydrate in apple leaves (Chong and Taper, 1971). Soil compaction had no effect on sorbitol in one of our studies (Table 5) and caused a 33\% reduction in sorbitol (Fig. 4C) in another.
These results in the second study occurred in the absence of statistically significant effects of compaction on $\mathrm{CO}_{2}$ assimilation rates. The depression of sorbitol concentration occurred in concert with a marked depression of shoot growth (Table 3), so it is possible that the relative lack of sorbitol availability in compacted plants plays a role in reducing plant growth. The increase in sorbitol concentration in apple leaves in response to moisture stress has been reported previously (Wang and Stutte, 1992). Compaction increased sucrose concentrations in leaves (Fig. 4A), suggesting diversion of hexose from sorbitol to sucrose, but the mechanism underlying this phenomenon could not be deduced from the analyses carried out in this study. In the short-term moisture study (Table 5), compaction caused a decrease in sucrose $7 \mathrm{~d}$ after initiation of moisture stress, but had no effect at $10 \mathrm{~d}$.

Soil compaction caused a large reduction in tree height, number of leaves, stem diameter, and leaf area (Tables 3 and 7). The interaction between compaction and moisture stress for height and number of leaves was statistically significant in both studies. For all the growth variables, the effect of moisture stress was smaller for trees growing in compacted soil than for trees in non-compacted soil. The sensitivity of shoot length and leaf development to soil compaction has also been shown for barley (Mulholland et al., 1996a) and sunflower (Andrade et al., 1993). These previous studies also showed that root growth was generally less affected than shoot growth, and that was confirmed in Table 3.

Alteration of nutrient uptake could provide a partial explanation for the reduction in growth caused by soil compaction, since leaf levels of $\mathrm{N}, \mathrm{Ca}, \mathrm{Mg}, \mathrm{Mn}, \mathrm{Na}$, and $\mathrm{Zn}$ were significantly reduced (Table 6 ). However, other elements, such as $\mathrm{P}, \mathrm{K}, \mathrm{B}$, and Fe, were increased in leaves of trees growing in compacted soil. Shierlaw and Alston (1984) suggested that inhibition of root elongation is not necessarily correlated with inhibited uptake of mineral nutrients because contact between roots and soil increases in compacted soils. Higher rates of Puptake per unit root length in compacted soils have been reported (Cornish et al., 1984). Krannitz et al. (1991) proposed that the increased uptake of $P$ could be the expression of a higher demand placed by the shoot on a smaller root system or brought about by root-induced changes in the rhizosphere. In our study, the concentrations of most of the mineral elements were in the sufficient range for apple; except for Ca concentration, which was $11 \%$ below the sufficiency range (Cahoon, 1985). A review of the effects of deficient $\mathrm{Ca}$ on apple tree growth indicates the greatest effect is on root growth (Boynton and Oberly, 1996). However, root dry weight in the present study was reduced less than shoots or leaves (Table 3 ); thus, nutrient deficiency caused by soil compaction was probably not responsible for the large growth reduction that occurred.

Sievers and Hensel (1991) suggested that the root cap is the site of perception of chemical and physical signals for the root. Thus, the root cap is likely the sensor of soil compaction. Sev- 

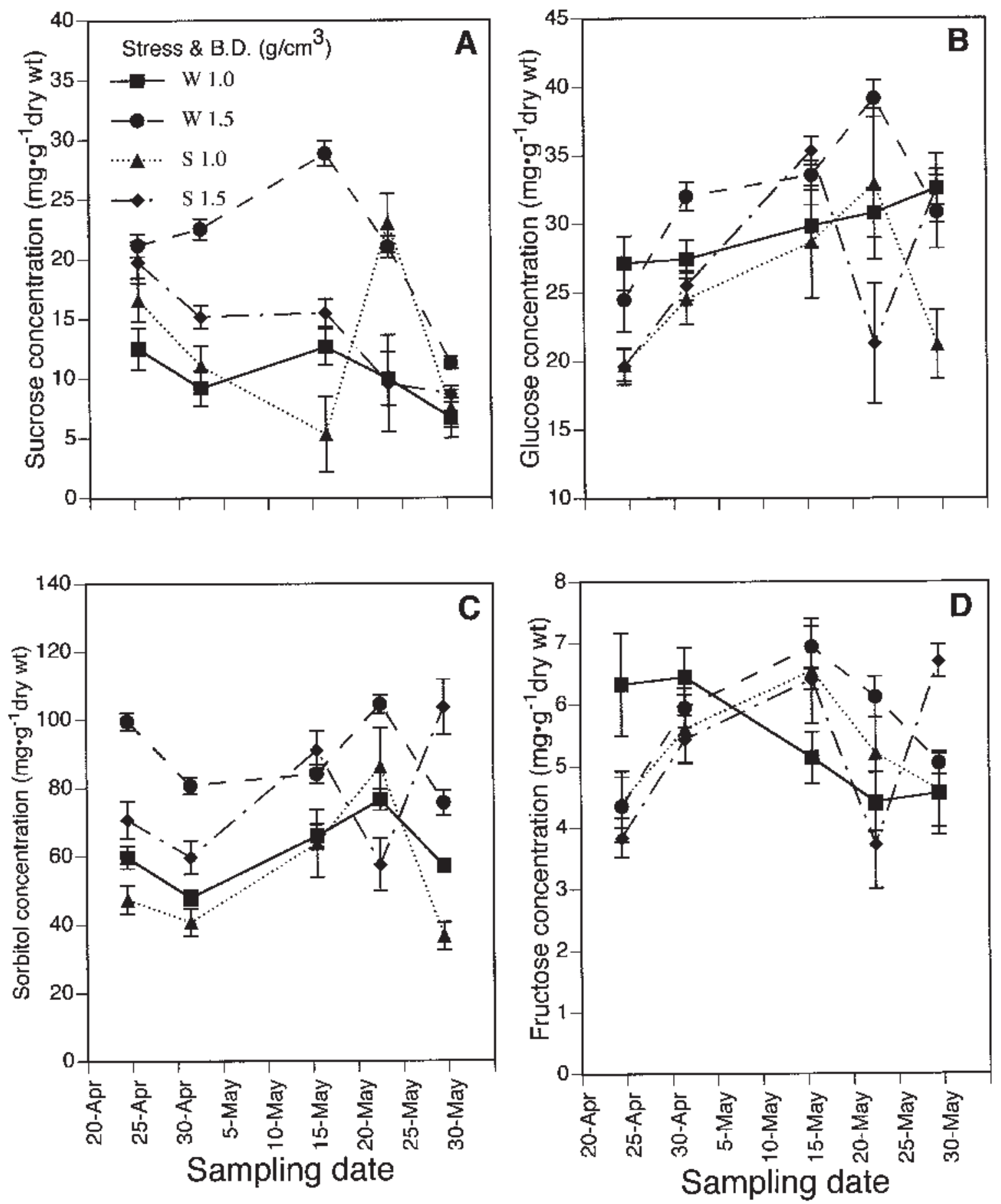

Fig. 4. Effect of container SBD and water stress (W = watered; S = not watered) on (A) sucrose, (B) glucose, (C) sorbitol, and (D) fructose concentration in 'M.9 EMLA' apple leaves. Soil was saturated with water just prior to 19 Apr. and just after 23 May.

eral investigators (Hussain et al., 1999a; Masle and Passioura, 1987; Mulholland et al., 1996a) suggested that root-derived hormonal signals were likely responsible for the growth reductions caused by soil compaction. Although we did not measure plant hormones, we did demonstrate that under greenhouse container conditions, a wide range of rootstocks were very tolerant of increasing soil compaction up to a bulk density of $1.4 \mathrm{~g} \cdot \mathrm{cm}^{-3}$. Trees on a wide range of rootstocks had significant reduction in growth when bulk density was increased to $1.5 \mathrm{~g} \cdot \mathrm{cm}^{-3}$ with 'B.9', 'M.7 EMLA', 'G.16', and 'G.30' being relatively tolerant and 'M.26
EMLA' and 'MM.106 EMLA' having greater reductions in total dry weight. Soil compaction that affected growth had little effect on photosynthesis but did alter carbohydrates in the leaves. Soil compaction slowed the decline in leaf RWC and transpiration under conditions of water stress. Soil compaction significantly altered leaf mineral concentrations, but the changes were unlikely to be responsible for the reduction in growth. Additional research is needed to see if the growth responses for soil compaction at a bulk density of $1.5 \mathrm{~g} \cdot \mathrm{cm}^{-3}$ or higher in these greenhouse studies will resemble responses to compaction in the field.

\section{Literature Cited}

Andrade,A., D.W. Wolfe, and E. Fereres. 1993. Leaf expansion, photosynthesis and water relations of sunflower plants grown in compacted soil. Plant Soil 149:174-184.

Blackwell, P.S., N.A. Ward, R.N. LeFevre, and D.J. Cowna. 1985. Compaction of a swelling clay soil by agricultural traffic. Effects upon conditions for growth of winter cereals and evidence for some recovery of structure. J. Soil Sci. 36: 633-650.

Boynton, D. and G.H. Oberly. 1966. Apple nutrition, p. 1-50. Nutrition of fruit crops. In: N.F Childers (ed.). Hort Publ., Rutgers State Univ., New Brunswick, N.J.

Brereton, J.C., M. McGowan, and T.C.K. Dawkins. 
1986. The relative sensitivity of spring barley, spring field beans, and sugar beet crops in soil compaction. Field Crops Res. 13:223-232.

Bulbotko, G.V. 1973. The effect of physical properties of soils on the development of the root system of apple trees. Soviet Soil Sci. USSR 5:219-224.

Cahoon, G.A. 1985. Fertilizing fruit crops. Ohio State Univ. Coop. Ext. Bul. 485.

Chong, C. and C.D. Taper. 1971. Daily variation of sorbitol and related carbohydrates in Malus leaves. Can. J. Bot. 49:173-177.

Conlin, T.S.S. and R. van den Driessche. 1996. Short term effects of soil compaction on growth of Pinus contorta seedlings. Can. J. For. Res. 26: 727-739.

Cornish, P.S., H.B. So, and J.R. McWilliam. 1984. Effect of SBD and water regime on root growth and uptake of phosphorus in ryegrass. Aust. J. Agr. Res. 35:631-644.

Daie, J. 1996. Metabolic adjustments in assimilate partitioning and alterations in source-sink relations in drought-stressed plants, p. 407-420. In: E. Zamski and A.A. Schaffer (eds.). Photoassimilate distribution in plants and crops.Marcel Dekker, New York.

Duffy, P.D. and D.C. McClurkin. 1974. Difficult eroded planting sites in north Mississippi evaluated by discriminate analyses. Soil Sci. Soc. Amer. Proc. 38:676-678.

Fernandez, R.T., R.L. Perry, and D.C. Ferree. 1995. Root distribution patterns of nine apple rootstocks in two contrasting soil types. J. Amer. Soc. Hort. Sci. 120:6-13.

Fernandez, R.T., R.L. Perry, and J.A. Flore. 1997. Drought response of young apple trees on three rootstocks. II. Gas exchange, chlorophyll fluorescence, water relations and leaf abscisic acid. J. Amer. Soc. Hort. Sci. 122:841-849.

Ferree, D.C. and J.C. Schmid. 2001. Apple rootstock reaction to soil compaction. Acta Hort. 557:111-115.

Gross, M.J. 1977. Effects of mechanical impedance on root growth in barley. I. Effect on the elongation and branching of seminal root axes. J. Expt. Bot. 28:96-111.

Gross, M.J. and R.S. Russell. 1980. Effects of mechanical impedance on root growth of barley.II. Observations on the mechanisms of response. J. Expt. Bot. 31:577-588.

Hulme, A.C. and L.S.C. Wooltorton. 1957. The organic acid metabolism of apple fruits:changes in individual acids during growth on the tree. J. Sci. Food. Agr. 8:117-122.

Hussain, A., C.R. Black, L.B. Taylor, B.J. Mulhol- land, and J.A. Roberts. 1999a. Novel approaches for examining the effects of differential soil compaction on xylem sap abscisic acid concentration, stomatal conductance and growth in barley (Hordeum vulgare L.). Plant Cell Environ. 22: 1377-1388.

Hussain, A., C.R. Black, L.B. Taylor, B.J. Mulholland, and J.A. Roberts. 1999b. Soil compaction. A role for ethylene in regulating leaf expansion and shoot growth in tomato. Plant Physiol. 121: 1227-1237.

Kays, S.J., C.W. Nicklow, and D.H. Simons. 1974. Ethylene in relation to the response of roots to physical impedance. Plant Soil 40:565-571.

Krannitz, P.G., L.W. Aarssen, and D.D. Lefebvre. 1991. Correction for non-linear relationships between root size and short term $\mathrm{P}$ uptake in genotype comparisons. Plant Soil 133:157-167.

Lo Bianco, R., M. Rieger, and S.-J.S. Sung. 2000. Effect of drought on sorbitol and sucrose metabolism in sinks and sources of peach. Physiol. Plant 108:71-78.

Loescher, W.H., G.C. Marlow, and R.A. Kennedy. 1982. Sorbitol metabolism and sink-source interconversions in developing apple leaves. Plant Physiol. 70:335-339.

Masle, J. 1992. Genetic variation in the effects of root impedance on growth and transpiration rates of wheat and barley. Aust. J. Plant Physiol. 19: 109-125.

Masle, J. and G.O. Farquhar. 1988. Effects of soil strength on the relation of water useefficiency and growth to carbon isotope discrimination in wheat seedlings. Plant Physiol. 86:32-38.

Masle, J. and J.B. Passioura. 1987. The effect of soil strength on the growth of young wheat plants. Aust. J. Plant Physiol. 14:643-656.

Maupin, C. and D.K. Struve. 1997. Red oak transplanted to different bulk density soils have similar water use characteristics. J. Arboricult. 23:233-238.

Mulholland, B.J., C.R. Black, L.B. Taylor, J.A. Roberts, and J.R. Lenton. 1996a. Effect of soil compaction on barley (Hordeum vulgare L.) growth. I. Possible role for ABA as a root- sourced chemical signal. J. Expt. Bot. 47:539-549.

Mulholland, B.J., C.R. Black, L.B. Taylor, J.A Roberts, and J.R. Lenton. 1996b. Effect of soil compaction on barley growth. II. Are increased xylem sapABAconcentrations involved in maintaining leaf expansion in compacted soils? J. Expt. Bot. 47:551-556.

Passioura, J.B. and P.A.Gardner. 1990. Control of leaf expression in wheat seedlings growing in a drying soil. Aust. J. Plant Physiol. 17:149-157.
Pilon-Smits, E.A.H., N. Terry, T. Sears, and K. vanDun. 1999. Enhanced drought resistance in fructan-producing sugar beet. Plant Physiol. Biochem. 37:313-317.

Psarras, G. and I.A. Merwin. 2000. Water stress effects rhizosphere respiration rates and root morphology of young 'Mutsu' apple trees on 'M.9' and 'MM.111' rootstocks. J. Amer. Soc. Hort. Sci. 125:588-595.

Ranney, T.G., N.I. Bassuk, and T.H. Whitlow. 1991. Osmotic adjustment and solute constituents in leaves and roots of water-stressed cherry (Prunus) trees. J. Amer. Soc. Hort. Sci. 116: 684-688.

Sarquis, J.L., W.R. Jordan, and P.W. Morgan. 1991. Ethylene evolution from maize (Zea mays L.) seedling roots and shoots in response to mechanical impedance. Plant Physiol. 96:1171-1177.

Shen, B., S. Hohmann, R.G. Jensen, and H.J. Bohnert. 1999. Roles of sugar alcohols in osmotic stress adaptation. Replacement of glycerol by mannitol and sorbitol in yeast. Plant Physiol. 121:45-52.

Shierlaw, J. and A.M. Alston. 1984. Effect of soil compaction on root growth and uptake of phosphorus. Plant Soil 77:15-28.

Sievers, A. and W. Hensel. 1991. Root cap, structure and function, p. 53-74 . In: V. Wassal, A. Eshel and U. Katkof (eds.). Plant roots, the hidden half. Marcel Dekker, New York.

Slowik, K. 1970. Influence of machinery compaction on the soil physical properties and apple tree growth (English summary). Prace Instytutu Sadonictiwa W. Skierniewicach. Tom XIV, p. 140.

Streeter, J.G. and C. E. Strimbu. 1998. Simultaneous extraction and derivatization of carbohydrates from green plant tissues for analysis by gasliquid chromatography. Anal. Biochem. 259: 253-257.

Tarczynski, M.C., R.G. Jensen, and H.J. Bohnert. 1993. Stress protection of transgenic tobacco by production of the osmolyte mannitol. Science 259:508-510.

Vepraskas, M.J. 1994. Plant response mechanisms to soil compaction, p. 263-287. In: R.E. Wilkinson (ed.). Plant-environment interactions. Marcel Dekker, New York.

Wang, Z. and G.W. Stutte. 1992. The role of carbohydrates in active osmotic adjustment in apple under water stress. J. Amer. Soc. Hort. Sci. 117: 816-823.

Watson, M.E. and R.A. Isaac. 1990. Analytical instruments for soil and plant analysis, p. 691-740. In: R.L. Westerman (ed.). Soil testing and plant analysis. Soil Sci. Soc. Amer., Madison, Wis. 